\title{
Reproducibility and Robustness of Microbial Fuel Cells Technology
}

Sara Mateo, Pablo Cañizares, Manuel Andrés Rodrigo and Francisco Jesús FernándezMorales*

University of Castilla-La Mancha, ITQUIMA, Faculty of Chemical Sciences \& Technologies, Chemical Engineering Department, Avenida Camilo José Cela, 12. 13071 Ciudad Real, Spain.

* Corresponding author: Francisco Jesus Fernández Morales University of Castilla-La Mancha, ITQUIMA, Chemical Engineering Dept., Avda. Camilo José Cela S/N 13071, Ciudad Real, Spain.

Tel: 0034926295300 (ext. 6350), Fax: 0034926295242.

E-mail: fcojesus.fmorales@uclm.es

Orcid iD: 0000-0003-0389-6247 


\section{Abstract}

This work focuses on the evaluation of the robustness and reproducibility of the behaviour of microbial fuel cells (MFCs). Up to 112 MFCs were operated simultaneously under the same conditions, finding that the probability of high performance, maximum power, maximum current and internal resistance is $95 \%, 90 \%$, $96 \%$ and $94 \%$ respectively. Reproducibility of stacks was also evaluated by testing different electrical connections, finding that when evaluating the performance of 7 stacks of 16 MFCs each connected in parallel and different combinations of series/parallel, the maximum power varies only between 1-2 $\mathrm{mW}$. Results obtained also helps to demonstrate that the performance of the bioelectrochemical devices evaluated mainly depended on the internal resistance. All these information is of a great significance for future developments of the technology because it is a real first step in the characterization of the robustness of the bioelectrochemical technology.

\section{Keywords}

Microbial fuel cell; robustness; reproducibility; green energy. 


\section{Introduction}

Microbial Fuel Cells (MFCs) are a promising green technology for a planet seriously affected by main problems related to traditional energy sources [1, 2]. This interest is reflected by the Web of Science database which index more than 7000 publications related to the keyword microbial fuel cell up to the end of 2018 [3]. However, MFCs are yet to be accepted by the market, being compulsory to demonstrate its robustness and reproducibility. Most of publications are scientific and not technical $[4,5]$, being focused on design parameters [6,7], selection of materials [8] and of selection of suitable operational conditions in order to enhance the MFC performance [9-15]. A very low percentage of the publications are focused on the modelling of this technology [16-18], trying to shed light on the understanding of the processes that take place in the MFC and its dependence on the design and operation [19, 20]. However, despite the number and the variety of publications, from the authors' knowledge there is no article that points out the reproducibility of this technology with a high number of MFCs tested. Nowadays, most of the cases reported MFCs data from two or three replications. For example, Philamore et al. worked with two MFC replicates [21]; Chouler et al., Yi et al. and Beecroft et al. carried out their study by using three replicates of the same MFC [22-24]. while, Tremoulia et al. investigated a 12 MFC stacks and checked the reproducibility of the test by using two similar stacks [25]. These replications allow to confirm the reproducibility of the data obtained in the study but neither the reproducibility of the technology nor its robustness. In this sense, the study of the reproducibility as well as the robustness of the MFC technology is of great interest. The reproducibility can be defined as the degree of agreement between 
the results of different experiments [26], while robustness is the ability to tolerate or overcome adverse conditions or rigorous testing [27]. In addition, the MFC technology is stagnated because of the limitations in the scale-up stage, which cannot lead to applicable devices, the variability of the performance reported in the large number of papers published and financial aspects [28]. With the aim to find its place in the market, authors consider that before carrying out economic estimations or real demonstrations it must be demonstrated the outstanding potential of this technology in terms of reproducibility and robustness. Thus, for MFCs, to find its place in the market, it is necessary to demonstrate also its robustness.

In the literature it has been described that higher yields should be obtained by the MFC in order to find real applications. Nowadays, the most convenient scale-up strategy is the connection of multiple small MFCs as a stack. This strategy has been suggested in several publications: in 2010, a robot provided with 48 mini MFCs connected as stack was able to store the energy that it generates by oxidising the food that it collected [29]. In 2017, 24 mini MFCs fed with real urine charged and power a smartphone Samsung Galaxy S 19000 [30]. Very recently, another work showed the continuous illumination of 220 LEDs with 112 mini stacked MFCs [31]. Because of that, real applications should be focused more on power technologies [30] [32] or sensors $[33,34]$ instead of the original concept of self-sufficient wastewater treatment plants [2] as small MFCs cannot face their typical high flow rates. In this context, this work aims to evaluate the robustness and reproducibility of the MFC technology by comparing the steady state performance for 112 MFCs, operating in single mode and connected into several stacks by using different statistical parameters. 


\section{Materials and methods}

The experimental set-up used in this wok consisted of 112 MFCs. Each MFC consisted of an anodic chamber of $0.695 \mathrm{~cm}^{3}$ separated from the cathode by a Nafion $\mathrm{N} 117^{\circledR}$ proton exchange membrane (DuPontTM). The anode was made of carbon felt (Sigracell ${ }^{\circledR}$ GF6EA) while the cathode, based on air breathing technology, was made of carbon paper (Freudenberg C2, Fuel Cell Products) modified by the addition of a catalytic layer of platinum. Both surface areas were $0.866 \mathrm{~cm}^{2}$. All these MFCs were identically constructed according to the standardized methodology previously described. This methodology was developed in previous studies in order to obtain an optimal performance of the MFC. The parameters and conditions evaluated were: anode material [35], cathode material [36], membrane [36], enrichment procedure [37], sludge age [38, 39], electron donor [40], electron acceptor [41] and configuration of stacks $[31,42]$. The electrodes were placed as close as possible to the membrane to reduce the internal resistance. It is important to highlight that $0.5 \mathrm{mg} \mathrm{Pt} \mathrm{cm}^{-2}$ was deposited on the cathode in order to avoid limitations in the MFCs and a Nafion proton exchange membrane was used to avoid short-circuiting the electrodes. In order to evaluate also the robustness of the stacking process, the 112 MFCs were placed in 7 stacks of 16 MFCs each one. 4 horizontal lines of 4 MFCs were connected hydraulically in cascade. Each cascade was connected to an auxiliary tank of $115 \mathrm{~mL}$. For the study of MFCs reproducibility, the electrodes of each MFC was connected externally by a load of $120 \Omega$ leading to an individual electric connection per MFC. For the stacking process, the MFCs were electrical connection in series/parallel. 
Each auxiliary tank was seed by using the effluent of an on-going MFCs and maintained under stirred conditions to avoid the settling of the sludge. This on-going MFCs was initially seed with conventional activated sludge taken from the aerobic reactor of a Wastewater Treatment Plant of Ciudad Real [43]. The solution of electrogenic bacteria was recirculated at a flow rate of $3 \mathrm{~mL} \mathrm{~min}^{-1}$ by the system during 24 hours. Then, the $50 \%$ of the solution was purged and fresh sludge was added. This procedure was carried out during the second and third day. The $4^{\text {th }}$ day, a sludge age of 2.5 days was established by removing $46 \mathrm{~mL}$ of suspension that was replaced by fresh synthetic wastewater.

The synthetic wastewater used as feedstock was prepared in the laboratory. Its composition was based on a simple, and easy to be degraded by bacteria [35], carbon source and nutrients: $16.10 \mathrm{~g} \mathrm{~L}^{-1}$ of sodium acetate, $1.25 \mathrm{~g} \mathrm{~L}^{-1}$ of calcium chloride, 2.77 $\mathrm{g} \mathrm{L}^{-1}$ of sodium carbonate, $0.92 \mathrm{~g} \mathrm{~L}^{-1}$ of hexahydrate magnesium chloride, $1.11 \mathrm{~g} \mathrm{~L}^{-1}$ of potassium dihydrogen phosphate, $1.85 \mathrm{~g} \mathrm{~L}^{-1}$ of ammonium sulphate and $0.07 \mathrm{~g} \mathrm{~L}^{-1}$ of ferric ammonium sulphate. In order to avoid its degradation, it was autoclaved at 105ㅇ C for 30 minutes [44].

For the electrochemical characterization, polarization curves were carried out at the steady state with a potenciostat/galvanostat AUTOLAB PGSTAT30 (Ecochemie, Netherlands) and GPES software, in potentiodynamic mode at a potential scanning from the OCV to $0.001 \mathrm{~V}$, a scan rate of $1-0.5 \mathrm{mV} \mathrm{s}^{-1}$, a pre-treatment stage of 4 minutes. 3 scans per polarization curve were performed to ensure accurate results. 


\section{Results and discussion}

In this work, the reproducibility of 112 MFCs and the reproducibility of 7 stacks, composed of 16 individual MFCs, were evaluated. It was observed that the time required by the 112 MFCs to achieve the steady state was about $19 \pm 2 \mathrm{~d}$.

\subsection{Study of reproducibility of MFCs}

The reproducibility of MFC technology was evaluated by the operation of 112 MFCs and, once reached the steady state, the main operational parameters were determined: open circuit voltage (OCV), maximum power, maximum current and internal resistance. Figure 1 shows the relative frequency histograms of those parameters.

As it can be observed, the $74 \%$ of the MFCs achieved an OCV between 0.4 and $0.5 \mathrm{~V}$ and only a $3 \%$ performed really badly $(0.2-0.3 \mathrm{~V})$. In addition, around the $8 \%$ reached higher values of OCV than $0.5 \mathrm{~V}$. Regarding to the maximum power, around the $75 \%$ of the MFCs generated maximum power densities higher than $1 \mathrm{~W} \mathrm{~m}^{-2}$, which indicates the superb performance of 74 MFCs. In addition, the $8 \%$ could achieve values greater than $3 \mathrm{~W} \mathrm{~m}^{-2}$ and only the $5 \%$ of the MFCs performed at the undesired range $(<0.5 \mathrm{~W}$ $\left.\mathrm{m}^{-2}\right)$. The highest maximum current densities $\left(>28 \mathrm{~A} \mathrm{~m}^{-2}\right.$ ) were achieved by the $4 \%$ of the MFCs while the $52 \%$ outperforms at the range of $8-16 \mathrm{~A} \mathrm{~m}^{-2}$ and $26 \%$ at the range of $16-28 \mathrm{~A} \mathrm{~m}^{-2}$. The $4 \%$ of the MFCs worked badly $\left(<5 \mathrm{~A} \mathrm{~m}^{-2}\right)$. 

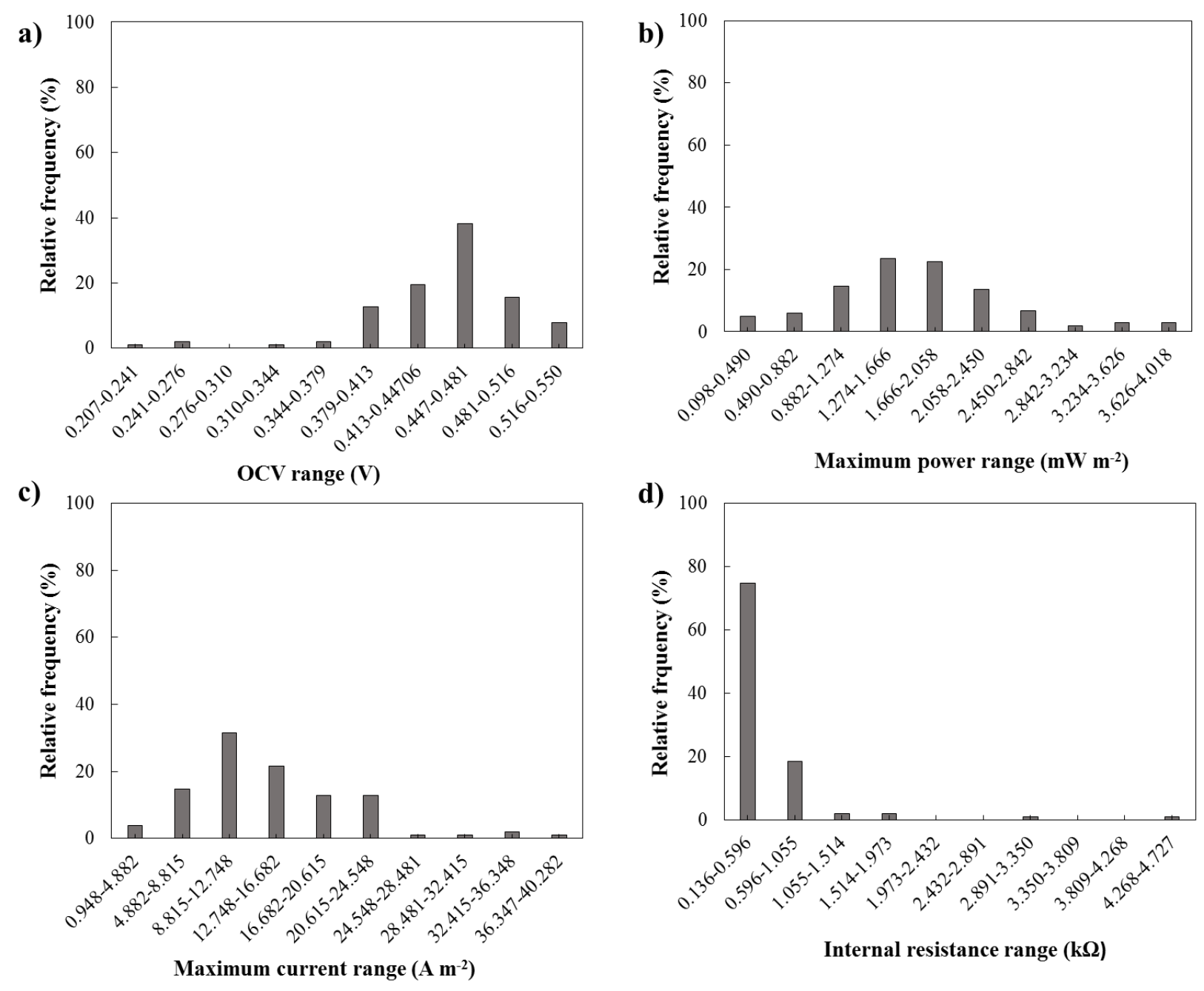

Figure 1. Relative frequency histograms of the OCV (a), maximum power (b), maximum current (c) and internal resistance (d).

At this point, it is important to compare the values obtained with reported data: $0.0073 \mathrm{~A} \mathrm{~m}^{-2}$ [22], $0.48 \mathrm{~A} \mathrm{~m}^{-2}$ [45], $0.8 \mathrm{~A} \mathrm{~m}^{-2}$ [46], $2.2 \mathrm{~A} \mathrm{~m}^{-2}$ [47], $9.0 \mathrm{~A} \mathrm{~m}^{-2}$ [48]. The results reported in the literature point out the superb performance of the MFC operated in this work.

The internal resistance plays an important role in the performance of MFC. Higher internal resistances are related to bad performance. In Fig 1.d, only the $6 \%$ of the MFCs had an internal resistance higher than $1 \mathrm{k} \Omega$ and the $76 \%$ of these MFCs are 
characterized by its lower internal resistance $(<0.5 \mathrm{k} \Omega)$. The low internal resistances obtained are due to the miniature size of the MFC. It reduces the spacing between electrodes and favours the mass transfer [22]. These results show a reproducible MFC performance because of rigorously following the construction and operation methodology previously described. Despite the efforts to avoid the effect of different COD concentrations along the MFC cascades, the bad performance can be due to influence of the position of the MFC in the cascade. This can lead to an unbalanced COD distribution because of COD excess in the influent [42], COD depletion $[49,50]$ or substrate fermentation processes [51]. In addition, despite of the superb enrichment procedure followed, the biofilm density and/or culture can be affected by the unbalanced COD distribution. Anyway, there is a low deviation percentage and attending to the performance of the MFCs, these results point out an efficient technology.

Figure 2 shows the ogives of the same parameters. An ogive represent the cumulative frequency for the different values of $\mathrm{OCV}$, maximum power and current and internal resistance in order to determine the number of values that are below a particular value. In this study, these figures are very useful to define the number of MFCs that work poorly. For example, 4 MFCs shows an OCV lower than $0.3 \mathrm{~V} ; 6$ MFCs, a maximum power density lower than $0.5 \mathrm{~W} \mathrm{~m}^{-2} ; 5 \mathrm{MFCs}$, a maximum current density lower than $5 \mathrm{~A} \mathrm{~m}^{-2}$. In the case of the internal resistance, it can be observed a high cumulative frequency at the lowest values of internal resistance and a constant trend at high values, indicating that only a small number of cells have high internal resistance. 
a)

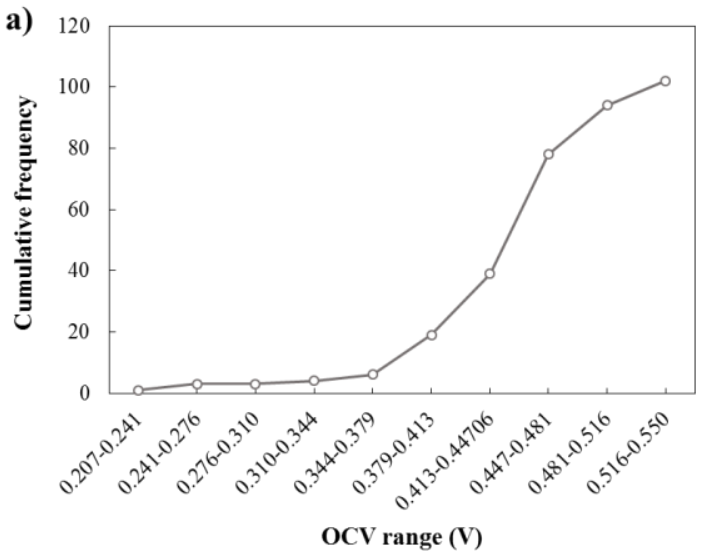

c)

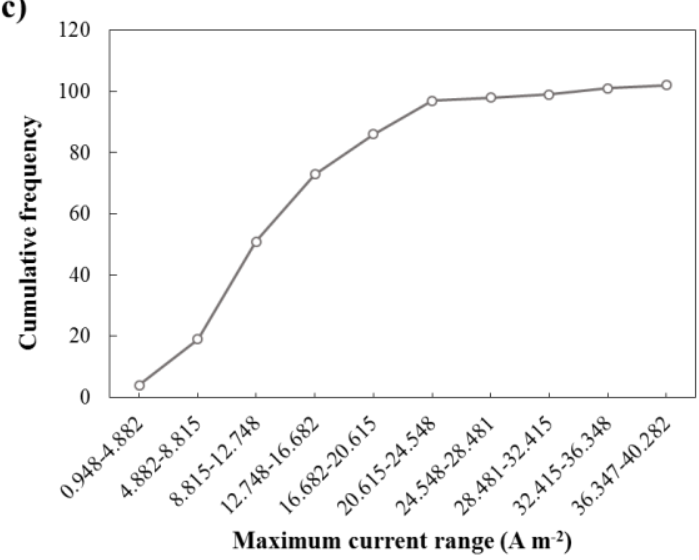

b)

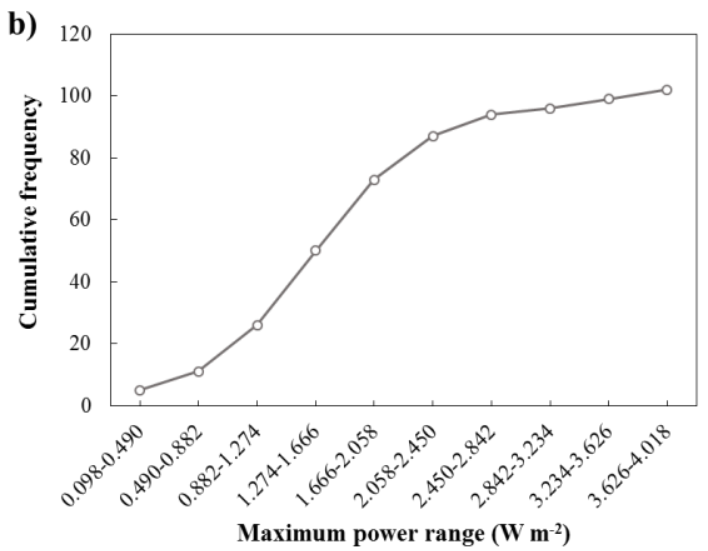

d)

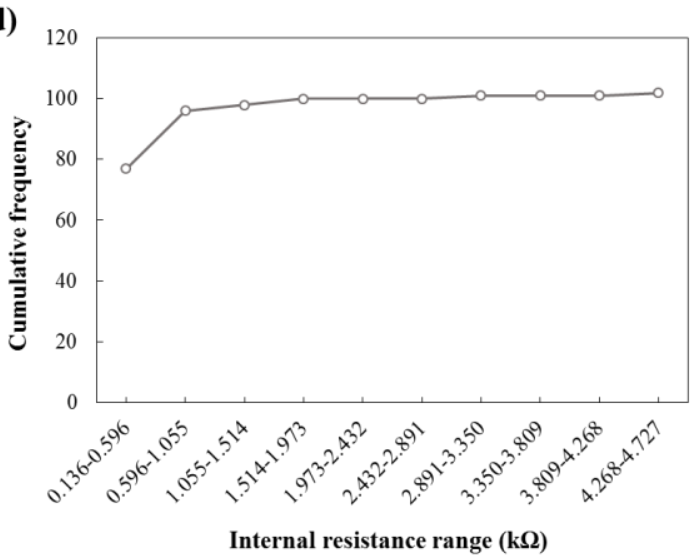

Figure 2. Ogive of OCV (a), maximum power (b), maximum current (c) and internal resistance (d).

In probability terms, the probability of good performance, maximum power, maximum current and internal resistance is $95 \%, 90 \%, 96 \%$ and $94 \%$ respectively. As it can be observed, the probability of operated an MFC successfully is $90 \%$ regardless of the parameter studied. This high percentage after having operated 112 similar MFCs simultaneously at the same conditions indicates a superb robustness of the MFC technology. This demonstration can be very useful from the commercial point of view. MFC technology is stagnated due to scale-up limitations [3] and to the topic of performance variability. This study faced the variability problem of MFCs showing a promising future for MFCs. 
More statistical information describing the behaviour of the MFC's are presented in Table 1.

Table 1. Statistical analysis of the MFC.

\begin{tabular}{|c|c|c|c|c|c|c|c|}
\hline & Average & Max. & Min. & Median & Fashion & $\begin{array}{l}\text { Standard } \\
\text { deviation }\end{array}$ & Variance \\
\hline OCV (V) & 0.450 & 0.550 & 0.207 & 0.457 & 0.452 & 0.053 & 0.003 \\
\hline$P_{\max }\left(W^{-2}\right)$ & 1.730 & 4.018 & 0.098 & 1.667 & 2.09 & 0.773 & 0.051 \\
\hline$J_{\max }\left(A m^{-2}\right)$ & 14.124 & 40.282 & 0.948 & 12.755 & 10.739 & 6.748 & 45.090 \\
\hline$R_{\text {int }}(k \Omega)$ & 0.536 & 4.727 & 0.137 & 0.412 & 0.302 & 0.565 & 316.285 \\
\hline & Kurtosis & Q1 & Q2 & Q3 & $\begin{array}{l}\text { Interquartile } \\
\text { range }\end{array}$ & $\begin{array}{l}\text { Semiinter- } \\
\text { quartile range }\end{array}$ & $\begin{array}{l}\text { Middle } \\
\text { Quartile }\end{array}$ \\
\hline OCV (V) & 5.552 & 0.431 & 0.457 & 0.479 & 0.047 & 0.024 & 0.454 \\
\hline$P_{\max }\left(W^{-2}\right)$ & 10.452 & 1.201 & 1.67 & 2.01 & 0.898 & 0.449 & 1.650 \\
\hline superbJ $_{\max }\left(A \mathrm{~m}^{-2}\right)$ & 2.351 & 9.963 & 12.755 & 17.046 & 7.0823 & 3.541 & 13.504 \\
\hline$R_{\text {int }}(k \Omega)$ & 0.033 & 0.293 & 0.412 & 0.539 & 0.247 & 0.247 & 0.416 \\
\hline
\end{tabular}

The average, the median and the fashion indicate the central values. The values of these parameters are very similar in all the cases, especially for the OCV and the maximum power. The error was calculated through the standard deviation (STDV), which reflects the deviation degree. When using the average as mean measure, The OCV is the parameter that showed the smallest STDV while the STDV of the internal resistance indicates that despite of the similar resistance in around $76 \%$ of the cases, the extreme values are very different. This fact can be observed in its maximum and minimum of 4.73 and $0.14 \mathrm{k} \Omega$, respectively. It is important to remark that only the $6 \%$ worked under internal resistances similar to the maximum. The variance values reflect the same trend than the standard deviation, remarking also how different are the 
extreme values of the internal resistance. It can be related to a bad assembly of the membrane-electrode or to a low electrogenic biofilm formation. This fact points out that the performance deviation can be due to a bad construction or enrichment process as a consequence of the human role instead of problems caused by the technology itself. The kurtosis indicates the amount of data that is close to the mean. The higher kurtosis, the higher data close to the average. The maximum power showed the higher kurtosis, followed by the OCV, the maximum current and finally, the internal resistance. Regarding to the quartiles (Q), Q2 is equal to the median. Q1 indicates that the $25 \%$ of the values are below Q1 value while Q3 indicates that the 75\% of the values are below Q3 value and the difference between both is the interquartile range. This dispersion parameter is used when considering the median as main mean measurement.

Finally, standardized normal distribution curves were studied in Figure 3. It is a function with three differentiated parts: the middle zone, whose centre is value of the mean and it is concave; and the two ends, which are convex and tend to approximate the $\mathrm{X}$ axis. The most common elements are in the centre zone while the most unusual values at the extremes. It shape is also related to the median, the fashion and the average. When fashion=average=median the curve is symmetrical. As these values are very similar in the case of the maximum power, its curve was practically symmetrical. In the case of the OCV, it was obtained a skewed curve to the left while for the maximum current and internal resistance, the curve was skewed to the right. The width of the curve indicates the data dispersion. The OCV curve is the narrowest one. 
a)
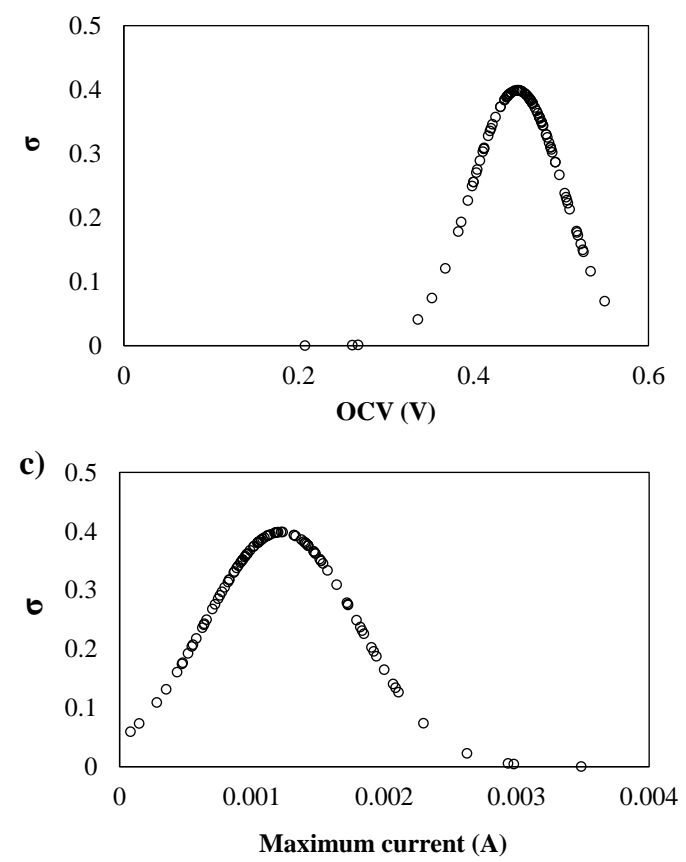

b)
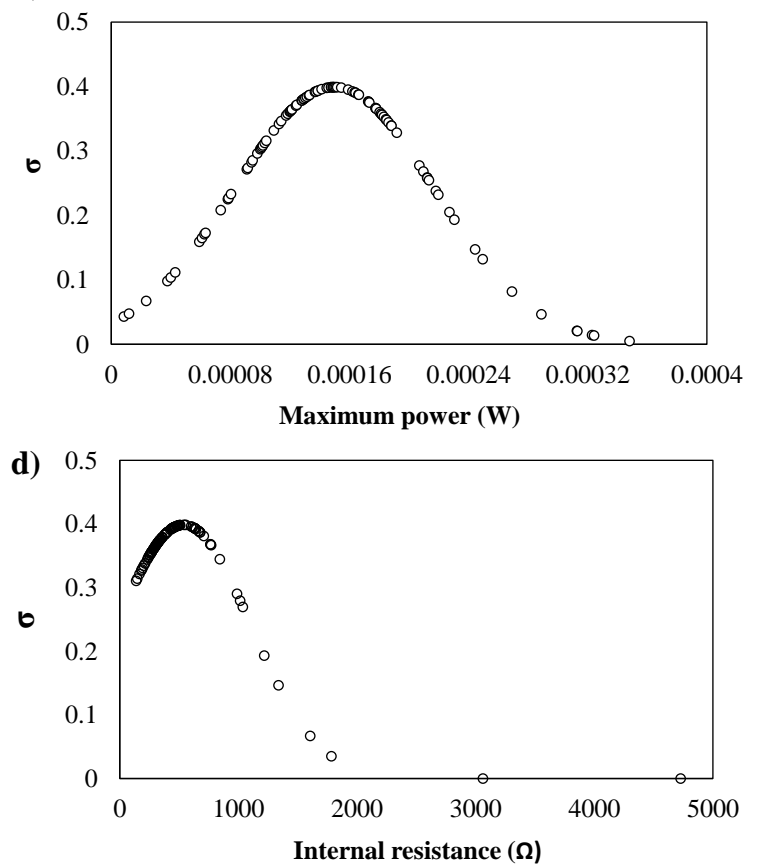

Figure 3. Standardized normal distribution curves of OCV (a), maximum power (b), maximum current (c) and internal resistance (d).

\subsection{Study of reproducibility of 7 stacks}

This section is focused on studying the reproducibility of the behaviour of 7 stacks.

Each stack has 16 MFCs. Therefore, the stack strategy followed the principle of the "miniaturization and multiplication" due to the MFC size and the stack design [52]. The stacks have been evaluated under different electrical connection in order to demonstrate its robustness regardless the electrical connection of the MFCs. The configurations tested were parallel and combinations of series/parallel 2/8 and 4/4.

The $2 / 8$ configuration consists of 2 groups of 8 MFCs, the MFCs were connected in parallel while the groups were connected in series. In the $4 / 4$ configurations, 4 groups were connected in series and each groups were formed by 4 MFCs connected in parallel. 
Figure 4 shows the OCV, maximum power and current and internal resistance (in logarithmic scale) for each stack and each connection.

a)

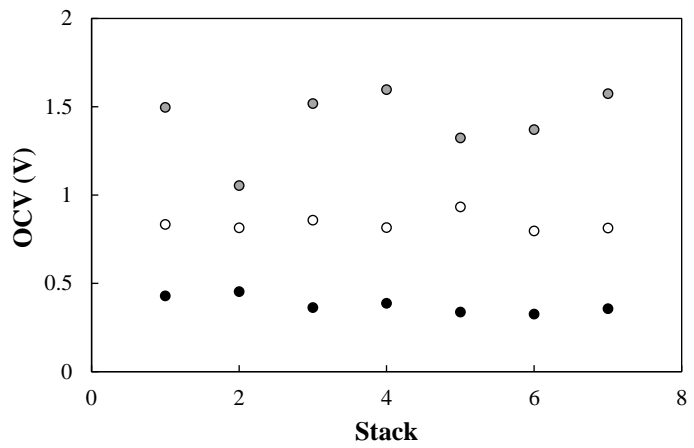

c)

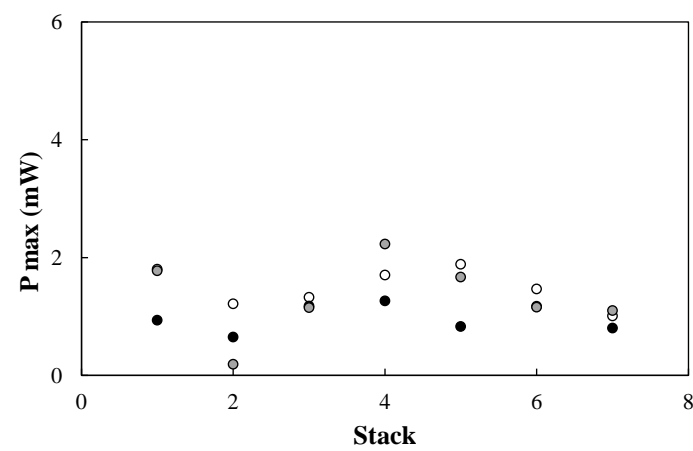

b)

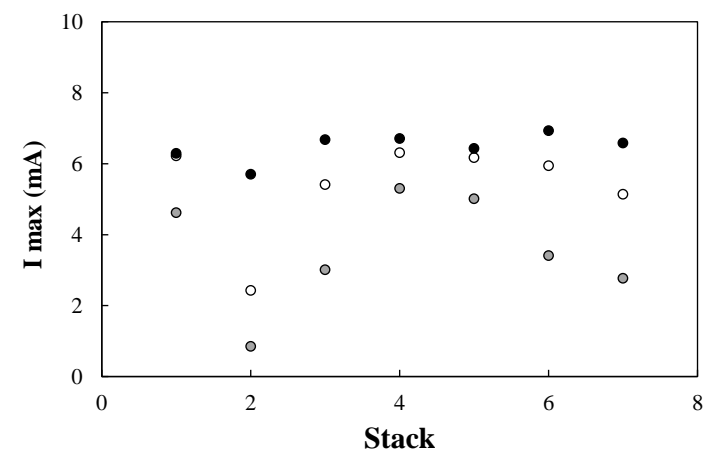

d)

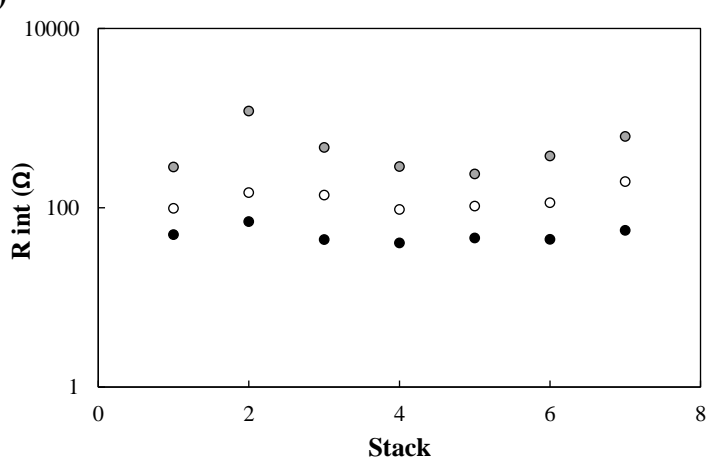

Figure 4. Performance of the stacks under different electrical connections. (•) Parallel;

(0) 2/8 combination; ( $\bullet$ ) 4/4 combination.

As can be seen in Figure 4, results were reproducible in each configuration but the performance of stack 2 deviated from the trend and this deviation was more remarkable in configurations of series/parallel combination. This behaviour could be related to reversal voltage, which is a common phenomenon when working in series, due to unbalanced substrate distribution or different microbial communities [53-55]. In addition, maximum power values showed oscillations when increasing the series connection but it varied between 1-2 $\mathrm{mW}$, which cannot be considered as a high 
difference. The OCV and the internal resistance followed the same trend without remarkable oscillations: the OCV increased when increasing the groups in series [28, 56] and the internal resistance decreased with parallel connections. The decrease of the internal resistance when connecting MFC stack in parallel has been reported in the literature [52]. Furthermore, the maximum current increased also with the number of MFCs in parallel $[28,56]$. The oscillations mentioned were confirmed by statistical parameters in Table 2.

Table 2. Statistical parameters for the stacks under different electrical connections.

\begin{tabular}{|c|c|c|c|c|c|c|c|c|}
\hline Connection & $\begin{array}{l}\text { OCV } \\
\text { (V) }\end{array}$ & $\begin{array}{l}P_{\max } \\
(\mathrm{mW})\end{array}$ & $\begin{array}{l}I_{\max } \\
\mathrm{mW}\end{array}$ & $\begin{array}{l}R_{\text {int }} \\
(k \Omega)\end{array}$ & $\begin{array}{l}\text { OCV } \\
\text { (V) }\end{array}$ & $\begin{array}{l}P_{\max } \\
(\mathrm{mW})\end{array}$ & $\begin{array}{l}I_{\max } \\
(\mathrm{mA})\end{array}$ & $\begin{array}{l}R_{\text {int }} \\
(k \Omega)\end{array}$ \\
\hline & \multicolumn{4}{|c|}{ Average } & \multicolumn{4}{|c|}{ Standard deviation } \\
\hline Parallel & 0.379 & 0.978 & 6.474 & 0.051 & 0.047 & 0.231 & 0.398 & 0.011 \\
\hline $2 / 8$ & 0.838 & 1.488 & 5.373 & 0.128 & 0.046 & 0.325 & 1.372 & 0.036 \\
\hline $4 / 4$ & 1.419 & 1.326 & 3.567 & 0.500 & 0.190 & 0.650 & 1.557 & 0.333 \\
\hline Connection & $\begin{array}{l}\text { OCV } \\
\text { (V) }\end{array}$ & $\begin{array}{l}P_{\max } \\
(\mathrm{mW})\end{array}$ & $\begin{array}{l}I_{\max } \\
(\mathrm{mA})\end{array}$ & $\begin{array}{l}R_{\text {int }} \\
(k \Omega)\end{array}$ & OCV (V) & $\begin{array}{l}P_{\max } \\
(\mathrm{mW})\end{array}$ & $\begin{array}{l}I_{\max } \\
(\mathrm{mA})\end{array}$ & $\begin{array}{l}R_{\text {int }} \\
(k \Omega)\end{array}$ \\
\hline & \multicolumn{4}{|c|}{ Maximum } & \multicolumn{4}{|c|}{ Minimum } \\
\hline Parallel & 0.454 & 1.270 & 6.930 & 0.706 & 0.326 & 0.653 & 5.689 & 0.041 \\
\hline $2 / 8$ & 0.933 & 1.877 & 6.311 & 1.967 & 0.796 & 0.192 & 2.426 & 0.096 \\
\hline $4 / 4$ & 1.597 & 2.232 & 5.300 & 1.204 & 1.054 & 1.010 & 0.849 & 0.240 \\
\hline
\end{tabular}

For the OCV, Table 2 reports a low STDV regardless the kind of connection due to maximum and minimum values around the average value. Regarding to the maximum power and current, the STDV is especially low in parallel and 2/8 combination. The 
STDV of the internal resistance in parallel and $2 / 8$ configuration indicates reproducible data but the high value of internal resistance, which is an extreme value (maximum) in stack 2 with $4 / 4$ configuration leads to a high STDV in this case. Anyway, in all the cases, the STDV increases when increasing the groups in series. However, the point is that, in general terms, attending to the same electrical connection, the values of STDV are acceptable. Because of that it can be stated that the data are reproducible as well as the technology is robust, not only for the operation of individual MFCs but also for the operation of MFC stacks. From the point of view of the scale-up, these results indicate that the miniaturization and multiplication strategy is viable because of the good performance and the reproducibility of the good performance in 7 stacks.

\subsection{Relationship performance-internal resistance}

As it was mentioned before, a low internal resistance can be linked with a good performance. For this reason, approach curves has been studied in this section considering the maximum power as the main parameter to represent the whole performance. In Fig. 5, it is shown the approach curve for individual MFCs. 


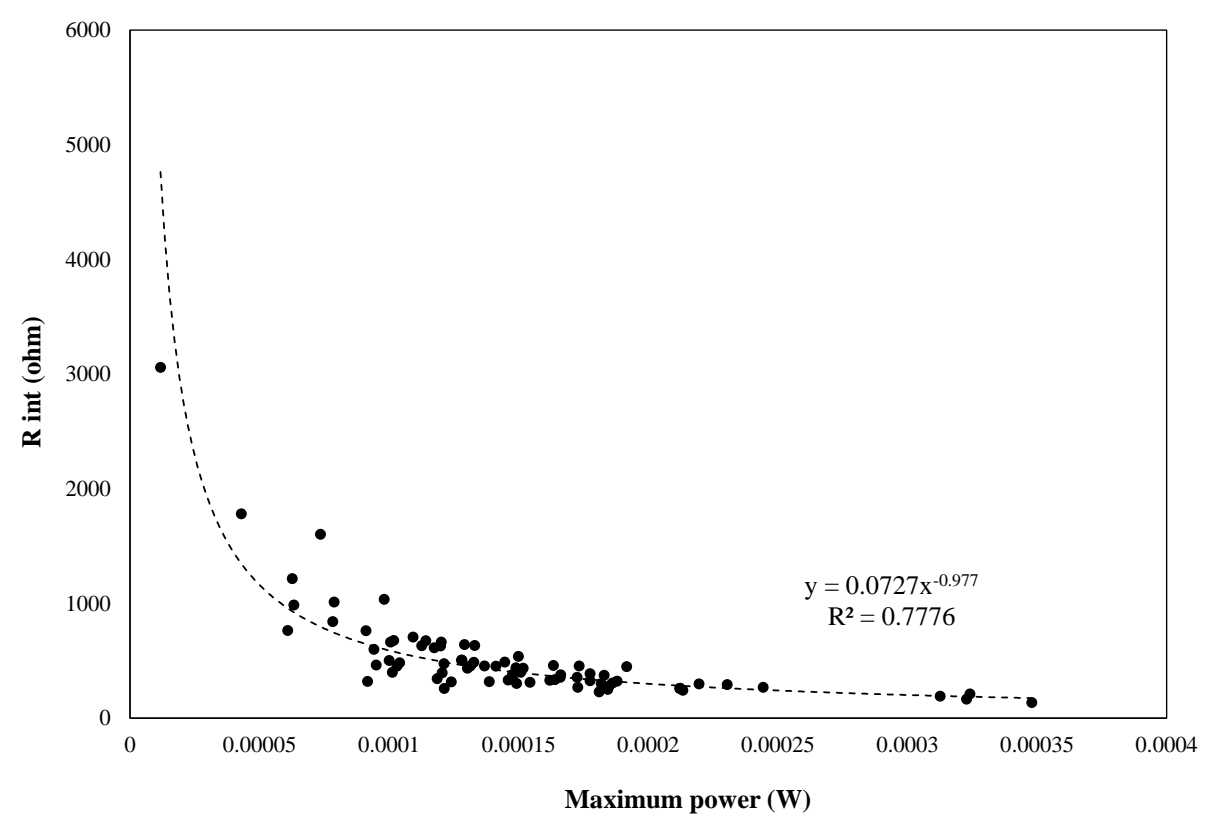

Figure 5. Internal resistance vs maximum power of individual MFCs.

It can be observed that high internal resistances results in low maximum power and vice versa. High internal resistances decrease the electrons rate from the anode to the cathode and means a potential energy loss. The experimental data was fitted to a potential curve with a correlation coefficient of 0.78 . This correlation coefficient increased up to 0.93 when attending to the fitting trends of the stacks for each electrical connection (Fig. 6). Fig. 6 demonstrates that regardless the number of MFCs and the way they are connected, the internal resistance and the performance are related by an exponential trend. 

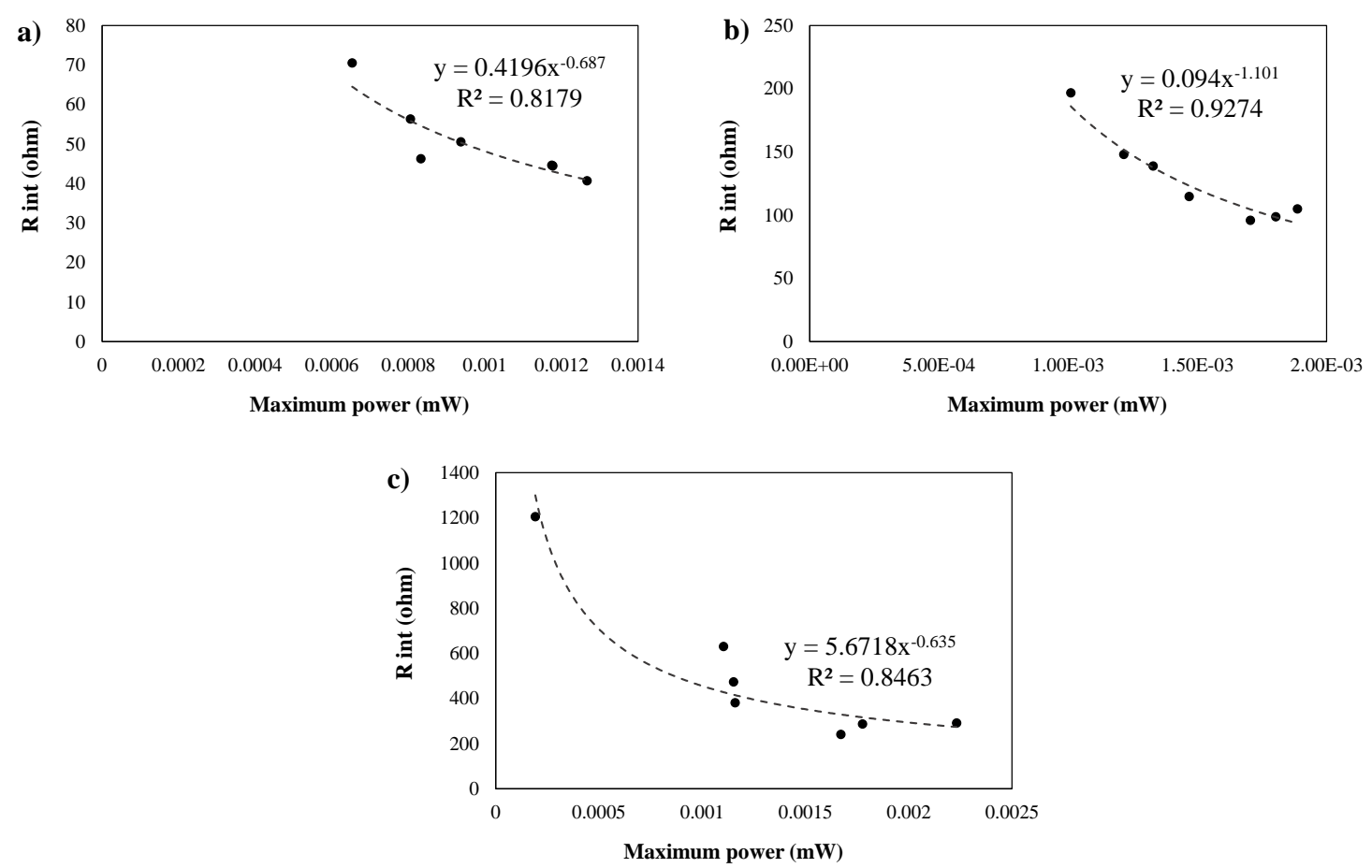

Figure 6. Internal resistance vs maximum power of the stacks under different electrical connections. (a) Parallel; (b) 2/8 combination; (c) 4/4 combination.

\section{Conclusions}

This work demonstrates the robustness of the MFC technology. After having operated 112 MFCs electrical connected individually, the statistical probability of good performance, maximum power, maximum current and internal resistance was $95 \%$, $90 \%, 96 \%$ and $94 \%$ respectively. These figures indicates that the MFC is a robust technology. When evaluating the performance of the MFC stacks it was observed that low STDV were obtained regardless the kind of electrical connection. Being the best stack configuration the parallel and 2/8 combination where the 8 MFCs were connected in parallel while the 2 groups were connected in series. Finally, it was demonstrated that the performance of the MFCs and of the stacks mainly depends on the internal resistance. These figures indicates that the MFC technology is both a 
reproducible and a robust technology, that could be used for real applications related to power technologies.

\section{Acknowledgements}

Authors are grateful for the financial support provided by the AEI (Agencia Estatal de Investigación) of the Spanish Ministry of Economy and Competitiveness (MINECO) through project CTQ2013-49748-EXP (Explora Program) and the Spanish Ministry of Education, Culture and Sport through the grant FPU 13/04118 of Sara Mateo. 


\section{References}

[1] Gonzalez del Campo A, Lobato J, Canizares P, Rodrigo MA, Fernandez Morales FJ. Shortterm effects of temperature and COD in a microbial fuel cell. Applied Energy 2013;101:213-7.

[2] Tommasi T, Lombardelli G. Energy sustainability of Microbial Fuel Cell (MFC): A case study. Journal of Power Sources 2017;356:438-47.

[3] Mateo S, Cañizares P, Fernandez-Morales FJ, Rodrigo MA. A critical view on microbial fuel cells: what's the next stage? ChemSusChem 2018;0(ja).

[4] Santoro C, Arbizzani C, Erable B, leropoulos I. Microbial fuel cells: From fundamentals to applications. A review. Journal of Power Sources 2017;356:225-44.

[5] González Del Campo A, Cañizares P, Rodrigo MA, Fernández FJ, Lobato J. Microbial fuel cell with an algae-assisted cathode: A preliminary assessment. Journal of Power Sources 2013;242:638-45.

[6] Ren H, Lee HS, Chae J. Miniaturizing microbial fuel cells for potential portable power sources: Promises and challenges. Microfluidics and Nanofluidics 2012;13(3):353-81.

[7] Wang Z, Mahadevan GD, Wu Y, Zhao F. Progress of air-breathing cathode in microbial fuel cells. Journal of Power Sources 2017;356:245-55.

[8] Erbay C, Yang G, De Figueiredo P, Sadr R, Yu C, Han A. Three-dimensional porous carbon nanotube sponges for high-performance anodes of microbial fuel cells. Journal of Power Sources 2015;298:177-83.

[9] Wu $\mathrm{Y}$, Yang $\mathrm{Q}$, Zeng $\mathrm{Q}$, Ngo HH, Guo W, Zhang H. Enhanced low C/N nitrogen removal in an innovative microbial fuel cell (MFC) with electroconductivity aerated membrane (EAM) as biocathode. Chemical Engineering Journal 2017;316:315-22.

[10] Park TJ, Ding W, Cheng S, Brar MS, Ma APY, Tun HM, et al. Microbial community in microbial fuel cell (MFC) medium and effluent enriched with purple photosynthetic bacterium (rhodopseudomonas sp.). AMB Express 2014;4(1):1-8.

[11] Inoue S, Parra EA, Higa A, Jiang Y, Wang P, Buie CR, et al. Structural optimization of contact electrodes in microbial fuel cells for current density enhancements. Sensors and Actuators, A: Physical 2012;177:30-6.

[12] Morris JM, Jin S. Influence of $\mathrm{NO}_{3}$ and $\mathrm{SO} 4$ on power generation from microbial fuel cells. Chemical Engineering Journal 2009;153(1):127-30.

[13] Cheng S, Liu H, Logan BE. Increased power generation in a continuous flow MFC with advective flow through the porous anode and reduced electrode spacing. Environmental Science and Technology 2006;40(7):2426-32.

[14] MacKie DM, Liu S, Benyamin M, Ganguli R, Sumner JJ. Direct utilization of fermentation products in an alcohol fuel cell. Journal of Power Sources 2013;232:34-41.

[15] Tice RC, Kim Y. Influence of substrate concentration and feed frequency on ammonia inhibition in microbial fuel cells. Journal of Power Sources 2014;271:360-5.

[16] Picioreanu C, Katuri KP, Van Loosdrecht MCM, Head IM, Scott K. Modelling microbial fuel cells with suspended cells and added electron transfer mediator. Journal of Applied Electrochemistry 2010;40(1):151-62.

[17] Zhao L, Naviaux J, Brouwer J, Hochbaum A. Modeling of polarization losses of a microbial fuel cell. ASME 2014 12th International Conference on Fuel Cell Science, Engineering and Technology, FUELCELL 2014 Collocated with the ASME 2014 8th International Conference on Energy Sustainability. 2014.

[18] Picioreanu C, van Loosdrecht MCM, Curtis TP, Scott K. Model based evaluation of the effect of $\mathrm{pH}$ and electrode geometry on microbial fuel cell performance. Bioelectrochemistry 2010;78(1):8-24. 
[19] Premier GC, Kim JR, Michie I, Dinsdale RM, Guwy AJ. Automatic control of load increases power and efficiency in a microbial fuel cell. Journal of Power Sources 2011;196(4):20139.

[20] Zhang L, Zhu X, Li J, Liao Q, Ye D. Biofilm formation and electricity generation of a microbial fuel cell started up under different external resistances. Journal of Power Sources 2011;196(15):6029-35.

[21] Philamore H, Rossiter J, Walters P, Winfield J, leropoulos I. Cast and 3D printed ion exchange membranes for monolithic microbial fuel cell fabrication. Journal of Power Sources 2015;289:91-9.

[22] Chouler J, Padgett GA, Cameron PJ, Preuss K, Titirici MM, leropoulos I, et al. Towards effective small scale microbial fuel cells for energy generation from urine. Electrochimica Acta 2016;192:89-98.

[23] Yi Y, Xie B, Zhao T, Li Z, Stom D, Liu H. Effect of external resistance on the sensitivity of microbial fuel cell biosensor for detection of different types of pollutants. Bioelectrochemistry 2019;125:71-8.

[24] Beecroft NJ, Zhao F, Varcoe JR, Slade RCT, Thumser AE, Avignone-Rossa C. Dynamic changes in the microbial community composition in microbial fuel cells fed with sucrose. Applied Microbiology and Biotechnology 2012;93(1):423-37.

[25] Tremouli A, Greenman J, leropoulos I. Investigation of ceramic MFC stacks for urine energy extraction. Bioelectrochemistry 2018;123:19-25.

[26] Plesser HE. Reproducibility vs. Replicability: A brief history of a confused terminology. Frontiers in Neuroinformatics 2018;11.

[27] Hampel FR. A General Qualitative Definition of Robustness. The Annals of Mathematical Statistics 1971;42(6):1887-96.

[28] leropoulos IA, Ledezma P, Stinchcombe A, Papaharalabos G, Melhuish C, Greenman J. Waste to real energy: the first MFC powered mobile phone. Physical Chemistry Chemical Physics 2013;15(37):15312-6.

[29] leropoulos I, Greenman J, Melhuish C, Horsfield I. EcoBot-III-A Robot with Guts.733-40.

[30] Walter XA, Stinchcombe A, Greenman J, leropoulos I. Urine transduction to usable energy: A modular MFC approach for smartphone and remote system charging. Applied Energy 2017;192:575-81.

[31] Mateo S, Cantone A, Cañizares P, Fernández-Morales FJ, Scialdone O, Rodrigo MA. Development of a module of stacks of air-breathing microbial fuel cells to light-up a strip of LEDs. Electrochimica Acta 2018.

[32] Parkash A. Microbial fuel cells: a source of bioenergy. J Microb Biochem Technol 2016;8:247-55.

[33] Kim BH, Chang IS, Gil GC, Park HS, Kim HJ. Novel BOD (biological oxygen demand) sensor using mediator-less microbial fuel cell. Biotechnology letters 2003;25(7):541-5.

[34] Chang IS, Jang JK, Gil GC, Kim M, Kim HJ, Cho BW, et al. Continuous determination of biochemical oxygen demand using microbial fuel cell type biosensor. Biosensors and Bioelectronics 2004;19(6):607-13.

[35] Mateo S, Cañizares P, Rodrigo MA, Fernandez-Morales FJ. Biofilm and planktonic population distribution. Key aspects in carbonaceous anodes for microbial fuel cells. Journal of Chemical Technology \& Biotechnology 2018;93(12):3436-43.

[36] Mateo S, Fernandez-Morales FJ, Canizares P, Rodrigo MA. Influence of the Cathode Platinum Loading and of the Implementation of Membranes on the Performance of AirBreathing Microbial Fuel Cells. Electrocatalysis 2017;8(5):442-9.

[37] Vicari F, Mateo S, Fernandez-Morales FJ, Canizares P, Galia A, Scialdone O, et al. Influence of the methodology of inoculation in the performance of air breathing microbial fuel cells. Journal of Electroanalytical Chemistry 2017;803:81-8. 
[38] D'Angelo A, Mateo S, Scialdone O, Canizares P, Fernandez-Morales FJ, Rodrigo MA. Optimization of the performance of an air-cathode MFC by changing solid retention time. Journal of Chemical Technology and Biotechnology 2017;92(7):1746-55.

[39] Mateo S, Zamorano-López N, Borras L, Fernandez-Morales FJ, Cañizares P, Seco A, et al. Effect of sludge age on microbial consortia developed in MFCs. Journal of Chemical Technology and Biotechnology 2018;93(5):1290-9.

[40] Mateo S, Cañizares P, Rodrigo MA, Fernandez-Morales FJ. Driving force of the better performance of metal-doped carbonaceous anodes in microbial fuel cells. Applied Energy 2018;225:52-9.

[41] Mateo S, Rodrigo M, Fonseca LP, Canizares P, Fernandez-Morales FJ. Oxygen availability effect on the performance of air-breathing cathode microbial fuel cell. Biotechnology Progress 2015;31(4):900-7.

[42] Mateo S, Cantone A, Cañizares P, Fernández-Morales FJ, Scialdone O, Rodrigo MA. On the staking of miniaturized air-breathing microbial fuel cells. Applied Energy 2018;232:18.

[43] Rodríguez Mayor L, Villaseñor Camacho J, Fernández Morales FJ. Operational optimisation of pilot scale biological nutrient removal at the Ciudad Real (Spain) domestic wastewater treatment plant. Water, Air, and Soil Pollution 2004;152(1-4):27996.

[44] Fernandez-Morales FJ, Villasenor J, Infantes D. Modeling and monitoring of the acclimatization of conventional activated sludge to a biohydrogen producing culture by biokinetic control. International Journal of Hydrogen Energy 2010;35(20):10927-33.

[45] Papaharalabos G, Stinchcombe A, Horsfield I, Melhuish C, Greenman J, leropoulos I. Autonomous Energy Harvesting and Prevention of Cell Reversal in MFC Stacks. Journal of The Electrochemical Society 2017;164(3):H3047-H51.

[46] Chang YY, Zhao HZ, Zhong C, Xue A. Effects of different Pt-M (M = Fe, Co, Ni) alloy as cathodic catalyst on the performance of two-chambered microbial fuel cells. Russian Journal of Electrochemistry 2014;50(9):885-90.

[47] Liu H, Cheng S, Logan BE. Production of electricity from acetate or butyrate using a single-chamber microbial fuel cell. Environmental Science and Technology 2005;39(2):658-62.

[48] Fan Y, Hu H, Liu H. Enhanced Coulombic efficiency and power density of air-cathode microbial fuel cells with an improved cell configuration. Journal of Power Sources 2007;171(2):348-54.

[49] Walter XA, Forbes S, Greenman J, leropoulos IA. From single MFC to cascade configuration: The relationship between size, hydraulic retention time and power density. Sustainable Energy Technologies and Assessments 2016;14:74-9.

[50] Fernández de Dios MÁ, del Campo AG, Fernández FJ, Rodrigo M, Pazos M, Sanromán MÁ. Bacterial-fungal interactions enhance power generation in microbial fuel cells and drive dye decolourisation by an ex situ and in situ electro-Fenton process. Bioresource Technology 2013;148:39-46.

[51] de los Angeles Fernandez M, de los Angeles Sanroman M, Marks S, Makinia J, Gonzalez del Campo A, Rodrigo M, et al. A grey box model of glucose fermentation and syntrophic oxidation in microbial fuel cells. Bioresource Technology 2016;200:396-404.

[52] leropoulos IA, Greenman J, Melhuish C. Miniature microbial fuel cells and stacks for urine utilisation. International Journal of Hydrogen Energy 2013;38(1):492-6.

[53] Aelterman P, Rabaey K, Pham HT, Boon N, Verstraete W. Continuous electricity generation at high voltages and currents using stacked microbial fuel cells. Environmental Science and Technology 2006;40(10):3388-94.

[54] Kim D, An J, Kim B, Jang JK, Kim BH, Chang IS. Scaling-Up Microbial Fuel Cells: Configuration and Potential Drop Phenomenon at Series Connection of Unit Cells in Shared Anolyte. ChemSusChem 2012;5(6):1086-91. 
[55] Zhuang L, Zhou S. Substrate cross-conduction effect on the performance of serially connected microbial fuel cell stack. Electrochemistry Communications 2009;11(5):93740.

[56] Dekker A, Ter Heijne A, Saakes M, Hamelers HVM, Buisman CJN. Analysis and improvement of a scaled-up and stacked microbial fuel cell. Environmental Science and Technology 2009;43(23):9038-42. 